\title{
PERAN SUPERVISI KEPALA DALAM MENINGKATKAN KOMPETENSI PEDAGOGIK GURU
}

(Studi di Madrasah Ibtidaiyah Ma'arif Adikarso Kabupaten Kebumen)

\author{
Bahrun Ali M urtopo dan ( Dosen) \\ Dian Efi Susanti ( Mahasiswa) \\ Institut Agama Islam Nahdlatul Ulama ( IAINU) Kebumen \\ bahrunalimurtopo@gmail.com \\ Dianefisusanti90@gmail.com
}

\begin{abstract}
ABSTRAK
Kepala madrasah mempunyai tanggungjawab dan peran terkait dengan kompetensi yang dimiliki oleh guru, salah satunya adalah kompetensi pedagogik. Peran supervisi yang dilakukan oleh kepala madrasah bertujuan untuk mengetahui sejauh mana guru dalam melaksanakan kegiatan belajar mengajar, guna meningkatkan profesionalisme guru. Penelitian ini bertujuan untuk mengetahui peran supervisi kepala madrasah dalam meningkatkan kompetensi pedagogik guru, mengetahui bagaimana efektivitas supervisi kepala madrasah dalam meningkatkan kompetensi pedagogik guru, serta untuk mengetahui faktor pendukung dan penghambat kepala madrasah dalam melaksanakan supervisi guna meningkatkan kompetensi pedagogik guru di M I Ma'arif Adikarso. Penelitian ini merupakan penelitian kualitatif dengan desain penelitian deskriptif. Adapun teknik pengumpulan data dilakukan dengan observasi, wawancara, dan dokumentasi. Hasil penelitian ini menunjukkan bahwa kepala madrasah telah berperan secara optimal dalam melaksanakan supervisi guna meningkatkan kompetensi pedagogik guru.
\end{abstract}

Kata Kunci : Peran, Kompetensi, Pedagogik Guru 


\section{A. Pendahulan}

Pendidikan adalah usaha sadar dan terencana untuk mewujudkan suasana belajar dan proses pembelajaran agar peserta didik secara aktif mengembangkan potensi dirinya untuk memiliki kekuatan spiritual keagamaan, pengendalian diri, kepribadian, kecerdasan, akhlak mulia, serta keterampilan yang diperlukan dirinya, masyarakat, bangsa dan Negara. ${ }^{1)}$

Sekolah/madrasah merupakan lembaga pendidikan yang memiliki peran penting dalam mewujudkan keberhasilan pendidikan. Pendidikan sangat penting dalam pembangunan suatu bangsa, serta bertujuan meningkatkan kualitas sumber daya manusia. M elalui pendidikan seseorang dibekali dengan berbagai pengetahuan, keterampilan dan keahlian.

Pada madrasah, tanggungjawab yang besar berada pada kepala madrasah sebagai seorang pemimpin. Kepala madrasah sebagai pemimpin lembaga pendidikan memiliki andil besar dalam menciptakan suasana kerja yang kondusif. Seorang kepala madrasah mempunyai tugas untuk mengatur dan menggerakkan orang atau guru yang memiliki berbagai sikap, tingkah laku dan latar belakang yang berbedabeda.

Kepala madrasah dalam melaksanakan tugasnya sebagai pemimpin, setidaknya bisa berperan sebagai pejabat formal, manajer, pemimpin, administrator, supervisor, innovator, dan motivator. ${ }^{2)}$ Seorang kepala madrasah juga memiliki kompetensi kepribadian, manajerial, kewirausahaan, supervisi dan sosial.

Kepala madrasah berperan dalam meningkatkan kinerja guru yang berada di dalam pengawasannya. Pengawasan tersebut adalah supervisi yang dilakukan oleh kepala madrasah. Kepala madrasah sebagai supervisor berkewajiban membina para guru agar menjadi pendidik dan pengajar yang baik. Berkaitan dengan hal tersebut kepala sekolah/madrasah sebagai supervisor mempunyai wewenang untuk mensupervisi guru-guru.

\footnotetext{
1) Memahami Paradigma Baru Pendidikan Nasional, (Jakarta: Ditjen Kelembagaan Agama Islam, 2003), hal. 34.

${ }^{2)}$ Muwahid Shulhan, Model Kepemimpinan Kepala Madrasah dalam Meningkatkan Kinerja Guru, (Yogyakarta: Teras, 2013), hal. 7.
} 
Kepala madrasah sebagai supervisor mempunyai tanggungjawab terhadap pembinaan dan pemberian bantuan terhadap guru-guru. Dalam perannya sebagai supervisor kepala sekolah/madrasah diharapkan dapat membantu guru-guru secara profesional untuk mengatasi masalah dalam kegiatan belajar mengajar. Bantuan dan pelayanan yang diberikan oleh kepala sekolah/madrasah disesuaikan dengan kebutuhan serta masalah yang sedang dihadapi oleh guru baik secara individu maupun kelompok.

Supervisi adalah suatu aktivitas pembinaan yang direncanakan untuk membantu para guru dan pegawai sekolah lainnya dalam melakukan pekerjaan mereka secara efektif. ${ }^{3)}$ Supervisi merupakan usaha memberikan layanan kepada guru-guru baik secara individu maupun secara kelompok dalam usaha memperbaiki pengajaran. ${ }^{4)}$

Sebagai supervisor sekaligus sebagai pemimpin kepala madrasah mempunyai peran yang besar dalam mengembangkan kualitas profesioanl guru, serta kualitas siswa atau madrasah yang secara umum ditentukan oleh kualitas kepala madrasah.

Guru merupakan salah satu komponen pokok dalam keberhasilan pendidikan. Dalam dunia pendidikan khususnya bidang pengajaran seorang guru merupakan ujung tombak dan menjadi tolak ukur dalam sukses tidaknya suatu proses kegiatan belajar mengajar. Guru yang profesional adalah guru yang mempunyai kompetensi pedagogik, kompetensi kepribadian, kompetensi profesional, dan kompetensi sosial. ${ }^{5)}$ Kompetensi guru merupakan perpaduan antara kemampuan personal, keilmuan, teknologi, sosial, dan spiritual yang secara kaffah membentuk kompetensi standar profesi guru. ${ }^{6)}$

Kompetensi pedagogik adalah kemampuan mengelola pembelajaran peserta didik yang meliputi pemahaman terhadap peserta didik, perancangan dan pelaksanaan pembelajaran, evaluasi hasil belajar, dan pengembangan peserta didik untuk mengaktualisasikan berbagai potensi yang dimilikinya. ${ }^{7)}$

\footnotetext{
${ }^{3)}$ Ngalim Purwanto, Administrasi dan Supervisi Pendidikan, (Bandung: Remaja Rosdakarya, 2004), hal. 76.

4) Piet A. Sahertian, Konsep Dasar dan Teknik Supervisi Pendidikan Dalam Rangka Pengembangan Sumber Daya Manusia, (Jakarta: Rineka Cipta, 2010), hal. 19.

${ }^{5)}$ Syaiful Sagala, Kemampuan Profesional Gurudan Tenaga Kependidikan, (Bandung: Alfabeta, 2009), hal. 30.

6) E. Mulyasa, Standar Kompetensi dan Sertifikasi Guru, (Bandung: PT Remaja Rosdakarya, 2008), hal. 26.

${ }^{7)}$ Ibid., hal. 75 .
} 
MI Ma'arif Adikarso sebagai salah satu lembaga pendidikan yang berada di bawah naungan Kementrian Agama merupakan madrasah yang mengembangkan pendidikan berbasis agama. MI Ma'arif Adikarso merupakan madrasah swasta yang sudah terakreditasi A dan madrasah masuk pada peringkat ke 11 dari semua sekolah yang ada di kecamatan kebumen. Semua itu tidak terlepas dari peran kepala madrasah dan semua jajarannya dalam pengelolaan manajemen. Terkait dengan perannya sebagai supervisor, kepala madrasah secara umum telah melaksanakan supervisi terhadap guru dalam melaksanaan kegiatan pembelajaran. Akan tetapi dalam melaksanakan pengawasan terhadap guru belum berjalan sesuai dengan rencana yang sudah ada. Pengawasan yang seharusnya dilakukan minimal dua kali dalam sebulan terkadang hanya dilaksanakan satu kali. Hal tersebut terjadi karena kesibukan kepala madrasah dalam melaksanakan berbagai tugas dan tanggung jawabnya. ${ }^{8}$

Berdasarkan uraian tersebut maka peneliti tertarik untuk mengadakan penelitian tentang Peran Supervisi Kepala Madrasah dalam Meningkatkan Kompetensi Pedagogik Guru di MI M a'arif Adikarso Kabupaten Kebumen.

\section{B. METODE PENELITIAN}

Dalam suatu penelitian metodologi mempunyai fungsi yang sangat penting yaitu berfungsi sebagai petunjuk penelitian yang dilaksanakan, selain itu berfungsi untuk mempermudah mencari informasi tentang apa yang akan diteliti. Penelitian ini dilaksanakan di lingkungan MI Ma'arif Adikarso Kecamatan Kebumen Kabupaten Kebumen Tahun Pelajaran 2016/2017.

Pendekatan penelitian yang penulis gunakan adalah penelitian kualitatif, yaitu data yang dikumpulkan adalah berupa kata-kata, gambar, dan bukan angkaangka. $^{9)}$

Menurut Bogdan dan Taylor (dalam Lexy J. Moleong) mendefinisikan penelitian kualitatif adalah sebagai prosedur penelitian yang menghasilkan data deskriptif berupa kata-kata tertulis atau lisan dari orang-orang dan perilaku yang

\footnotetext{
${ }^{8}$ Bahrun ali murtopo dan fatmawati 2016. Upaya Madrasah Dalam Meningkatkan Prestasi Un Mi Imam Puro Lubangindangan Kec Butuh Kab Purworejo. Jurnal penelitian bidang pendidikan. Vol.22,No.2 : 109-119.

${ }^{9)}$ Lexy J. Moleong, Metodologi Penelitian Kualitatif, (Bandung: PT. Remaja Rosdakarya, 2015), hal. 11.
} 
dapat diamati. ${ }^{10) .}$ Penelitian kualitatif ditujukan untuk memahami fenomenafenomena sosial dari sudut atau perspektif partisipan. Partisipan adalah orang-orang yang diajak wawancara, diobservasi, dan diminta untuk memberikan data, pendapat, pemikiran, dan persepsinya. ${ }^{11)}$

Pendekatan kualitatif dengan jenis penelitian deskriptif digunakan untuk mendeskripsikan peran yang dilakukan oleh Kepala madrasah sebagai supervisor dalam meningkatkan kompetensi pedagogik guru di MI Ma'arif Adikarso Kabupaten Kebumen Tahun Pelajaran 2016/2017.

Desain penelitian yang digunakan dalam penelitian ini yaitu desain penelitian deskriptif. Penelitian deskriptif merupakan metode penelitian yang berusaha mengungkap fakta suatu kejadian, objek, aktivitas, proses dan manusia secara apa adanya pada waktu sekarang atau jangka waktu yang masih memungkinkan dalam ingatan responding. ${ }^{12)}$

Penelitian deskriptif merupakan penelitian yang menggambarkan tentang keadaan yang sedang terjadi. Sehingga dapat disimpulkan jika penelitian ini akan mendeskripsikan dan menguraikan secara sistematis bagaimana peran supervisi kepala madrasah dalam meningkatkan kompetensi guru di MI Ma'arif Adikarso.

Reduksi data (data reduction) Data yang diperoleh selama melakukan proses penelitian pastinya jumlahnya cukup banyak dan beragam sehingga perlu di catat secara teliti, rinci dan sistematis kemudian dilakukan analisis data melalui reduksi data. Mereduksi data berarti merangkum, memilih hal-hal yang pokok, memfokuskan pada hal-hal yang penting, dicari tema dan polanya. ${ }^{13) . ~ D e n g a n ~}$ demikian data yang sudah direduksi akan menghasilkan gambaran data yang jelas bagi peneliti sehingga mempermudah dalam pengumpulan data.

\footnotetext{
10) Ibid., hal. 4.

11) Nana Syaodih Sukmadinata, Metode Penelitian Pendidikan, (Bandung: PT. Remaja Rosdakarya, 2012), hal. 94.

${ }^{12)}$ Andi Prastowo, Memahami Metode-metode Penelitian, (Jogjakarta: Ar-ruzz Media, 2011), hal. 203.

${ }^{13)}$ Sugiyono, Memahami Penelitian Kualitatif, (Bandung: Alfabeta, 2010), hal. 92.
} 


\section{HASIL PENELTIAN}

\section{a. Gambaran Umum MI Ma'arif Adikarso}

MI Ma'arif Adikarso terletak di jalan Keputihan RT: 01 RW: IV Desa Adikarso, Kecamatan Kebumen, Kabupaten Kebumen. Lokasi ini sangat strategis karena posisi madrasah berada di samping jalan desa yang sudah beraspal sehingga mudah untuk diakses dan juga dekat dengan Pondok Pesantren Darussalam.

MI Ma'arif Adikarso berdiri pada tanggal 1 Juni 1956. Berdasarkan musyawarah dan mufakat antara ulama dan tokoh masyarakat Desa Adikarso yang diprakarsai oleh Bapak M uhadjir dan Bapak H.Zaenuddin (Alm). Pada waktu itu diberi nama Madrasah Al-Islamiyah yang kemudian pada tanggal 1 Januari 1978 menjadi Madrasah Ibtidaiyah Islamiyah berdasarkan surat keputusan Departemen Agama Rl; Mk./3.4/922/P.P.35/1978. Kemudian pada tahun 1992 Madrasah masuk yayasan Ma'arif. Pada tanggal 1 Oktober 1993 MI Ma'arif Adikarso dengan surat keputusan Departemen Agama No.M k.28/V/PP.01.1/789/1993 dinyatakan bahwa statusnya telah "DIAKUI".

Sejak berdirinya sampai sekarang MI Ma'arif Adikarso telah mengalami beberapa kali pergantian Kepala M adrasah yaitu sebagai berikut:

\section{b. Peran Supervisi Kepala Madrasah dalam Meningkatkan Kompetensi Pedagogik}

\section{Guru}

Dari hasil observasi yang peneliti lakukan jika kepala madrasah menjalankan kewajibannya sebagai seorang pemimpin di lingkungan MI Ma'arif Adikarso, dan berhubungan langsung dengan pelaksanaan program pendidikan di madrasah. Kepala Madrasah juga mampu mengkondisikan anggotanya supaya dalam melaksanakan proses kegiatan belajar mengajar berjalan dengan baik dan dapat mencapai tujuan yang telah ditentukan. ${ }^{14)}$

Berdasarkan hasil wawancara dengan kepala madrasah, jika telah melaksanakan tugasnya sebagai supervisor, yaitu melaksanakan supervisi melalui supervisi kelas, menggunakan pendekatan kolaboratif, dan model supervisi klinis. ${ }^{15)}$

\footnotetext{
14) Hasil observasi di, pada 8 Oktober 2016.

${ }^{15)}$ Wawancara dengan Kepala Bapak Ahmad Suwardi, pada 10 Oktober 2016.
} 
Menurut Bapak Ahmad Suwardi, kegiatan supervisi kelas merupakan kegiatan pokok dalam upaya peningkatan kualitas guru. Supervisi dilakukan dengan melihat situasi, kondisi, dan kepentingan. Pelaksanaan supervisi dilakukan dalam satu bulan minimal dua kali untuk masing-masing kelas, pada saat melaksanakan supervisi kelas menggunakan instrumen. ${ }^{16)}$

Berdasarkan hasil wawancara peneliti dengan kepala madrasah, melalui pendekatan kolaboratif beliau memberikan saran, masukan, bantuan kepada guru. Selanjutnya mendengarkan informasi, cerita atau keluhan dari guru, kemudian memberikan saran terhadap masalah yang ada kemudian dicari jalan keluarnya secara bersama-sama. Model supervisi menggunakan model supervisi klinis menyangkut tentang pengawasan kelas yang difokuskan pada perbaikan pengajaran. ${ }^{17)}$

Menurut kepala madrasah, pengawasan dan evaluasi proses pembelajaran dilakukan melalui beberapa tahap yaitu:

1. Menyusun program pengawasan dan evaluasi proses pembelajaran.

2. Melaksanakan pengawasan dan evaluasi pembelajaran secara menyeluruh, meliputi perencanaan, pelaksanaan, dan hasil pembelajaran.

3. Melakukan pengawasan dan evaluasi proses pembelajaran kepada semua guru. $^{18)}$

Pengawasan dan evaluasi proses pembelajaran dilakukan oleh kepala madrasah secara berkala dan berkelanjutan. Kepala madrasah dalam melaksanakan kegiatan tidak terlepas dari berbagai program kerja yang sudah ada. Berikut ada 6 program kerja yang harus dilakukan oleh kepala madrasah yaitu meliputi: ${ }^{19)}$

\begin{tabular}{|l|l|l|l|l|l|}
\hline $\begin{array}{l}\text { Kegiatan } \\
\text { Harian }\end{array}$ & $\begin{array}{l}\text { Kegiatan } \\
\text { M ingguan }\end{array}$ & $\begin{array}{l}\text { Kegiata } \\
\mathrm{n} \\
\text { Bulana } \\
\mathrm{n}\end{array}$ & $\begin{array}{l}\text { Kegiatan } \\
\text { Semester }\end{array}$ & $\begin{array}{l}\text { Kegiatan Akhir } \\
\text { Tahun } \\
\text { Pelajaran }\end{array}$ & $\begin{array}{l}\text { Kegiatan } \\
\text { Awal Tahun } \\
\text { Pelajaran }\end{array}$ \\
\hline a. Memerik & a. Melaksa & b. Kegi & a. Menyelengg & d. Menyeleng & h. Merenca \\
\hline
\end{tabular}

\footnotetext{
16) ibid

${ }^{17)}$ Wawancara dengan Kepala Bapak Ahmad Suwardi, pada 10 Oktober 2016.

${ }^{18)}$ Wawancara dengan Kepala Bapak Ahmad Suwardi, pada 10 Oktober 2016.

${ }^{19)}$ Observasi di MI Ma'arif Adikarso Kebumen, pada 13 Oktober 2016.
} 


\begin{tabular}{|c|c|c|c|c|c|c|c|}
\hline$g$ & 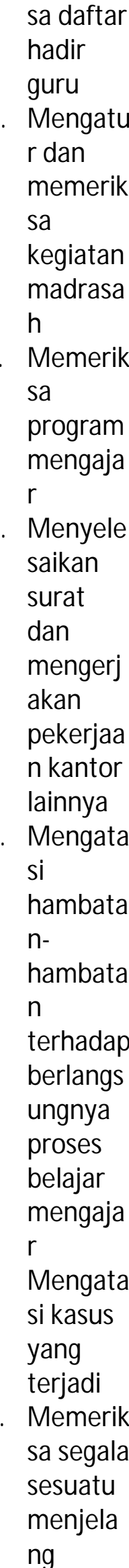 & d. & $\begin{array}{l}\text { nakan } \\
\text { upacara } \\
\text { bendera } \\
\text { pada } \\
\text { hari } \\
\text { senin } \\
\text { dan } \\
\text { hari- } \\
\text { hari } \\
\text { besar } \\
\text { M elaksa } \\
\text { nakan } \\
\text { senam } \\
\text { bersam } \\
\text { a } \\
\text { Memeri } \\
\text { ksa } \\
\text { agenda } \\
\text { dan } \\
\text { menyel } \\
\text { esaikan } \\
\text { surat } \\
\text { menyur } \\
\text { at } \\
\text { Mengad } \\
\text { akan } \\
\text { rapat } \\
\text { minggu } \\
\text { an } \\
\text { untuk } \\
\text { menjadi } \\
\text { bahan } \\
\text { rencana } \\
\text { kegiatan } \\
\text { minggu } \\
\text { an } \\
\text { M emeri } \\
\text { ksa } \\
\text { keuanga } \\
\text { n } \\
\text { sekolah } \\
\text { M engat } \\
\text { ur dan } \\
\text { penga } \\
\text { pasi }\end{array}$ & $\begin{array}{l}\quad \text { atan } \\
\quad \text { di } \\
\text { awal } \\
\text { bula } \\
\text { n } \\
\text { b. } \\
\text { Kegiata } \\
\text { n di } \\
\text { ahir } \\
\text { bulan }\end{array}$ & $\begin{array}{l}\text { arakan } \\
\text { pelaksanaan } \\
\text { ulangan } \\
\text { umum } \\
\text { semester } \\
\text { b. } \text { M enyelengg } \\
\text { arakan } \\
\text { evaluasi } \\
\text { kegiatan } \\
\text { pengajaran } \\
\text { c. Menyelengg } \\
\text { arakan } \\
\text { kegiatan ahir } \\
\text { semester }\end{array}$ & $\begin{array}{l}\text { garakan } \\
\text { penutupan } \\
\text { buku dan } \\
\text { inventaris } \\
\text { keuangan } \\
\text { e. } \text { M enyeleng } \\
\text { garakan } \\
\text { ulangan } \\
\text { umum dan } \\
\text { ujian ahir } \\
\text { f. Kegiatan } \\
\text { kenaikan } \\
\text { kelas dan } \\
\text { kelulusan } \\
\text { g. Menyeleng } \\
\text { garakan } \\
\text { evaluasi } \\
\text { pelaksanaa } \\
n \text { program } \\
\text { madrasah }\end{array}$ & $\begin{array}{l}\text { nakan } \\
\text { kebutuh } \\
\text { an guru } \\
\text { setiap } \\
\text { mapel } \\
\text { i. } \\
\text { Pembagi } \\
\text { an tugas } \\
\text { mengaja } \\
\text { r } \\
\text { j. Menyus } \\
\text { un } \\
\text { program } \\
\text { pengajar } \\
\text { an, } \\
\text { jadwal } \\
\text { pelajara } \\
\text { n dan } \\
\text { kaldik } \\
\text { k. M enyus } \\
\text { un } \\
\text { kebutuh } \\
\text { an buku } \\
\text { pelajara } \\
\text { n, buku } \\
\text { peganga } \\
\text { n guru } \\
\text { M enyus } \\
\text { un } \\
\text { kelengka } \\
\text { pan alat } \\
\text { pengajar } \\
\text { an dan } \\
\text { bahan } \\
\text { pelajara } \\
\text { n } \\
\text { m. M engad } \\
\text { akan } \\
\text { rapat } \\
\text { guru }\end{array}$ \\
\hline
\end{tabular}




\begin{tabular}{|l|l|l|l|l|}
\hline sekolah & aan & & & \\
usai & keperlu & & & \\
Melaksa & an & & & \\
nakan & madras & & & \\
pengawa & ah & & & \\
san & & & & \\
kegiatan & & & & \\
belajar & & & & \\
mengaja & & & & \\
r & & & & \\
\hline
\end{tabular}

Peran kepala madrasah sebagai supervisor dalam meningkatkan kompetensi pedagogik guru di MI Ma'arif Adikarso diantaranya yaitu:

1. Melaksanakan pengawasan kegiatan pembelajaran di kelas

Pelaksanaan pengawasan kegiatan pembelajaran di kelas bertujuan untuk memonitoring kerja guru. Dengan adanya pengawasan diharapkan guru semakin terampil dalam mengajar sehingga tercipta keberhasilan pembelajaran. Menurut wawancara dengan Bapak Wasilan, kepala madrasah dalam melaksanakan supervisi kelas tidak selalu berada di dalam kelas, adakalanya ikut masuk di dalam kelas dan adakalnya hanya mengamati dari luar kelas. ${ }^{20)}$

2. Membantu menyelesaikan masalah yang dihadapi guru

Menurut kepala madrasah, sudah menjadi tugasnya sebagai kepala madrasah untuk membantu menyelesaikan masalah yang dihadapi guru serta mencarikan solusi yang terbaik. Apabila ada masalah segera diselesaikan sehingga tidak berlarut-larut. ${ }^{21)}$

Berdasarkan wawancara antara peneliti dengan guru bahwa:

"kepala madrasah sebagai pengawas telah melaksanakan kegiatan diskusi dengan guru yang bertujuan untuk mengevaluasi kerja guru dalam melaksanakan tugas. Kepala madrasah selalu memberi arahan, bimbingan, saran dan masukan baik setelah upacara bendera maupun dalam waktuwaktu tertentu. Kepala madrasah juga sangat pro aktif ikut terlibat dalam pembicaraan individu terhadap masing-masing guru untuk menggali aspirasi demi tercapainya keberhasilan pembelajaran". ${ }^{22)}$

\footnotetext{
${ }^{20)}$ Wawancara dengan Bapak Wasilan Guru Kelas IV Kebumen, pada 20 Oktober 2016.

${ }^{21)}$ Wawancara dengan Kepala Adikarso Kebumen Bapak Ahmad Suwardi, pada 10 Oktober 2016.

${ }^{22)}$ Wawancara dengan Ibu Murniati Guru Kelas V Adikarso Kebumen, pada 12 Oktober 2016.
} 
3. Meningkatkan program pengajaran

Program pengajaran dibuat dengan tujuan agar dalam melaksanakan proses pembelajaran menjadi terarah, sehingga dalam menyampaikan materi tidak menyimpang dari pokok pembahasan sehingga tujuan pendidikan dapat tercapai. Program pengajaran yang sudah tersusun dengan rapi akan memudahkan ketika akan melaksanakan berbagai kegiatan, baik itu program harian, mingguan, atau tahunan.

Menurut hasil wawancara dengan Ibu Puji Lestari bahwa, kepala madrasah selalu memantau perkembangan metode/model pembelajaran, menilai administrasi kelas, dan memberi arahan tentang perangkat pembelajaran. $^{23)}$

4. Memberikan arahan agar tepat sasaran dan sesuai kurikulum

Pergantian kurikulum yang ada di sekolah dari KTSP ke K.13 sangat berpengaruh terhadap kegiatan pembelajaran. Guru perlu menyesuaikan diri dan beradaptasi dengan kurikulum yang baru.

Menurut Bapak Ahmad Suwardi, sebagai kepala madrasah harus membimbing dan mengarahkan guru-guru dalam merancang dan membuat komponen pembelajaran agar sesuai dengan kurikulum yang ada, sehingga materi pembelajaran yang disampaikan sesuai. ${ }^{24)}$

Sedangkan menurut wawancara dengan Ibu Surati bahwa, kepala madrasah selalu memberi saran dan masukan terhadap guru dalam meningkatkan program pengajaran, baik melalui pelatihan, workshop maupun KKG. Kepala madrasah sangat disiplin dan juga bersikap terbuka terhadap semua guru. $^{25)}$

Jadi sebagai kepala madrasah harus benar-benar menguasai kurikulum yang ada di madrasah. Melalui penguasaan kurikulum kepala madrasah dapat memberikan arahan kepada guru sehingga dapat diketahui berbagai kekurangan maupun kelemahan ketika proses pengajaran sedang berlangsung. Sedangkan bagi guru kurikulum merupakan sebuah pedoman yang dibutuhkan baik sebelum

\footnotetext{
${ }^{23)}$ Wawancara dengan Ibu Puji Lestari Guru Kelas I, pada 11 Oktober 2016.

${ }^{24)}$ Wawancara dengan Kepala Bapak Ahmad Suwardi, pada 10 Oktober 2016.

${ }^{25)}$ Wawancara dengan Ibu Surati Guru Kelas I, pada 29 September 2016.
} 
melakukan kegiatan pembelajaran maupun saat proses belajar mengajar dan bahkan setelah proses pembelajaran berlangsung.

5. M eningkatkan sarana prasarana

Kegiatan pembelajaran akan berjalan dengan baik dengan dukungan sarana prasarana yang memadai, tanpa sarana prasarana pembelajaran yang memadai maka bisa dipastikan kegiatan pembelajaran tidak akan berjalan sesuai dengan tujuan yang diharapkan.

Dari hasil wawancara dengan kepala madrasah, bahwa:

"sebagai kepala madrasah saya selalu berusaha untuk meningkatkan sarana prasarana yang belum lengkap dengan menyediakan anggaran dana. Adanya peningkatan sarana prasarana ditujukan agar pelaksanaan pembelajaran berjalan dengan baik dan berhasil lebih baik" ${ }^{26)}$

6. Menciptakan komunikasi yang baik

Terciptanya komunikasi yang baik di lingkungan madrasah tidak terlepas dari seluruh anggota madrasah itu sendiri. Komunikasi dengan menggunakan pilihan bahasa yang tepat dan sesuai diharapkan dapat menumbuhkan kedekatan emosional yang baik dan harmonis.

Dari hasil wawancara dengan kepala madrasah, bahwa:

"sebagai kepala madrasah saya selalu menghimbau kepada guru apabila melakukan komunikasi di lingkungan madrasah menggunakan bahasa yang baik dan santun. Karena apapun yang dilakukan dan di ucapkan oleh guru akan ditiru atau dicontoh oleh siswa". ${ }^{27)}$

Upaya yang dilakukan kepala madrasah untuk menunjang kompetensi pedagogik guru di MI Ma'arif Adikarso yaitu melalui: ${ }^{28)}$

1. Pelatihan maupun workshop

M I Ma'arif Adikarso pernah melaksanakan pelatihan ICT dari Australia, pelatihan PM R dan berbagai pelatihan lainnya.

KKG dilakukan bersama-sama dengan guru se-kecamatan Kebumen, dengan adanya KKG diharapkan dapat menambah wawasan ilmu pengetahuan yang baru, dapat tukar menukar pengalaman yang berhubungan dengan kegiatan pembelajaran.

\footnotetext{
26) Wawancara dengan Kepala Bapak Ahmad Suwardi, pada 10 Oktober 2016.

27) ibid

28) ibid
}

11 Jurnal Kajian Manajemen Pendidikan Islam dan Studi Sosial| Cakrawala.Vol.1No.1.2017 


\section{c. Efektivitas Supervisi Kepala Madrasah dalam Meningkatkan Kompetensi Pedagogik} Guru

Kompetensi pedagogik pada dasarnya adalah kemampuan guru dalam mengelola pembelajaran mulai dari persiapan, pelaksanaan serta pengelolaan kelas, penggunaan metode dan media, evaluasi serta penilaian pembelajaran bagi siswa. Kemampuan guru dalam mengembangkan kompetensi pedagogik sangat berpengaruh terhadap efektivitas pembelajaran yang dilakukan.

Adapun efektivitas supervisi yang dilakukan kepala madrasah dalam meningkatkan kompetensi pedagogik guru antara lain dalam hal:

\begin{tabular}{|c|c|l|}
\hline 1 & $\begin{array}{c}\text { Model } \\
\text { Supervisi }\end{array}$ & $\begin{array}{l}\text { Supervisi atau pengawasan yang dilakukan oleh } \\
\text { kepala madrasah terhadap guru dalam memberikan } \\
\text { arahan menggunakan model supervisi klinis }\end{array}$ \\
\hline 2 & Pendekatan & $\begin{array}{l}\text { Pendekatan yang digunakan oleh kepala madrasah } \\
\text { dalam melaksanakan pengawasan terhadap guru } \\
\text { yaitu melalui pendekatan kolaboratif. }\end{array}$ \\
\hline 3 & Supervisi & $\begin{array}{l}\text { Kepala madrasah dalam melaksanakan pengawasan } \\
\text { terhadap kegiatan pembelajaran yang dilakukan oleh } \\
\text { guru menggunakan teknik individu. }\end{array}$ \\
\hline
\end{tabular}

\section{Faktor Pendukung dan Penghambat dalam Meningkatkan Kompetensi Pedagogik}

Kepala Madrasah dalam melakukan pengawasan terhadap guru yang berhubungan dengan kompetensi pedagogik pastinya tidak terlepas dari faktor pendukung dan penghambat. Diantara faktor-faktor tersebut adalah:

1. Faktor Pendukung

a. Kemampuan guru

Menurut Bapak Ahmad Suwardi, sebagai seorang guru harus menguasai berbagai kemampuan, salah satunya dalam mengembangkan kepribadian, menguasai bahan pengajaran dan menyusun program pengajaran, menilai proses pembelajaran serta hasilnya, melakukan 
bimbingan belajar terhadap siswa, menjalin hubungan/kerjasama dengan sesama guru dan lingkungan madrasah. ${ }^{29)}$

Berdasarkan hasil wawancara dengan kepala madrasah dapat disimpulkan bahwa kemampuan guru di MI Ma'arif Adikarso sudah memadai, hal itu terbukti dengan kegiatan pembelajaran sudah berjalan dengan baik dan lancar, apabila ada siswa yang sepenuhnya belum menguasai materi pelajaran maka guru akan membimbingnya di ahir pelajaran. Hubungan yang dibangun sesama guru juga sangat kompak dan erat, begitupun dengan hubungan dengan masyarakat sekitar.

b. Latar belakang pendidikan

Menurut Bapak Ahmad Suwardi bahwa, latar belakang pendidikan seorang guru sangat berpengaruh besar terhadap prestasi belajar siswa, karena ada perbedaan antara cara mengajar seorang guru yang berilmu dan berpendidikan tinggi dengan seorang guru yang perpendidikan rendah. ${ }^{30}$

Berdasarkan hasil observasi dijelaskan bahwa, guru-guru di MI Ma'arif Adikarso semuanya merupakan lulusan S1 kependidikan. ${ }^{31)}$

2. Faktor Penghambat

1. Sarana prasarana yang masih kurang lengkap

Berdasarkan hasil wawancara antara peneliti dengan kepala madrasah, dijelaskan bahwa:

"sarana prasarana di MI Ma'arif Adikarso disana sini masih banyak kekurangan dan masih sangat terbatas jumlahnya, diantaranya jumlah LCD proyektor yang masih kurang, buku paket pelajaran untuk kurikulum terbaru yang jumlahnya masih terbatas, gedung/ruang yang masih kurang apalagi dengan bertambahnya siswa yang masuk di MI Ma'arif Adikarso". ${ }^{32)}$

Berdasarkan observasi yang peneliti lakukan untuk sarana dan prasarana penunjang pembelajaran memang masih kurang lengkap, seperti buku paket yang ada di perpustakaan yang jumlahnya masih sangat terbatas.

\footnotetext{
${ }^{29)}$ Wawancara dengan Kepala MI Ma'arif Adikarso Bapak Ahmad Suwardi, pada 10 Oktober 2016

${ }^{30)}$ Wawancara dengan Kepala MI Ma'arif Adikarso Bapak Ahmad Suwardi, pada 10 Oktober 2016

${ }^{31)}$ Hasil Observasi, pada 13 Oktober 2016

${ }^{32)}$ Wawancara dengan Kepala MI Ma'arif Adikarso BapakAhmad Suwardi, pada 10 Oktober 2016.
} 
Mushola dan perpustakaan yang sementara waktu masih dijadikan dalam satu ruangan karena kekurangan ruang/gedung.

2. Kemampuan individu guru yang tidak sama

Menurut Bapak Ahmad Suwardi, kemampuan yang dimiliki guru di sini antara yang satu dengan yang lainnya berbeda, banyak faktor yang mempengaruhi salah satunya yaitu faktor usia, pengalaman mengajar, masa kerja guru, dan lain sebagainya. ${ }^{33)}$

Berdasarkan hal tersebut dapat disimpulkan bahwa secara tidak langsung perbedaan kemampuan guru dapat menghambat maupun mengurangi efektifitas dalam berbagai proses kegiatan pembelajaran.

\section{Kesimpulan}

Berdasarkan hasil penelitian yang telah penulis lakukan, maka penulis menarik kesimpulan sebagai berikut:

7. Sebagai supervisor pendidikan kepala madrasah telah melaksanakan supervisi dalam meningkatkan kompetensi pedagogik guru di MI Ma'arif Adikarso dengan baik. Dalam melaksanakan pengawasan kepala madrasah menggunakan model klinis, pendekatan kolaborasi, supervisi dilakukan dalam satu bulan dua kali. Peran kepala madrasah dalam melaksanakan supervisi yaitu: melaksanakan pengawasan kegiatan pembelajaran di kelas, membantu menyelesaikan masalah yang dihadapi guru, meningkatkan program pengajaran, memberikan arahan agar tepat sasaran dan sesuai kurikulum, meningkatkan sarana prasarana, menciptakan komunikasi yang baik.

8. Efektivitas supervisi yang dilakukan kepala madrasah cukup efektif dengan adanya peningkatan guru dalam hal persiapan mengajar, pengelolaan kelas, pemilihan dan penggunaan metode serta media, evaluasi dan penilaian, penggunaan media elektronik.

9. Faktor pendukung dalam meningkatkan kompetensi pedagogik guru yaitu kemampuan guru dan latar belakang pendidikan. Sedangkan faktor penghambat

${ }^{33)}$ Wawancara dengan Kepala MI Ma'arif Adikarso Bapak Ahmad Suwardi, pada 10 Oktober 2016. 
dalam meningkatkan kompetensi pedagogik guru yaitu sarana prasarana yang masih kurang lengkap dan kemampuan individu guru yang tidak sama. 


\section{Daftar Pustaka}

E. Mulyasa, Standar Kompetensi dan Sertifikasi Guru, (Bandung: PT Remaja Rosdakarya, 2008),

Agus maimun dan Agus zainul fitri, Madrasah Unggulan Lembaga Pendidikan Alternatif di Era Kompetitif, (M alang :UIN M ALIKI PRESS, 2010),

Wahjosumidjo, Kepemimpinan Kepala Sekolah Tinjauan Teoritik dan Permasalahannya, (Jakarta: PT Raja Grafindo Persada, 2003),

Soetjipto dan Raflis Kosasi, Profesi Keguruan, (Jakarta: Rineka Cipta, 2011),

http://sukabumikota.kemenag.go.id/file/dokumen/D001643.pdf tentang Permendiknas Republik Indonesia Nomor 13 Tahun 2007, diakses 27 Agustus 2016 jam 18.16.

Wahyudi, Kepemimpinan Kepala Sekolah dalam Organisasi Pembelajaran (Learning Organizatiton), (Bandung: CV. Alfabeta, 2012),

Luk-luk Nur M ufidah, Supervisi Pendidikan, (Yogyakarta: Teras, 2009),

Daryanto, Administrasi Pendidikan, (Jakarta: Rineka Cipta, 2010),

Suharsimi Arikunto, Dasar-Dasar Supervisi, (Jakarta: Rineka Cipta, 2004),

M ukhtar dan Iskandar, Orientasi Baru Supervisi Pendidikan, (Jakarta: Gaung Persada Press, 2009),

Herabudin, Administrasi \& Supervisi Pendidikan, (Bandung: Pustaka Setia, 2009),

Sri Banun M uslim, Supervisi Pendidikan M eningkatkan Kualitas Profesionalisme Guru, (Bandung: Alfabeta, 2010),

Sri Banun M uslim, Supervisi Pendidikan Meningkatkan Kualitas Profesionalisme Guru, (Bandung: Alfabeta, 2010),

Norma Dewi Shalikhah, Kepala Madrasah Sebagai Supervisor Pendidikan Dalam Pengembangan Kompetensi Guru Di MIN Kebonagung Imogiri Bantul Yogyakarta, (Yogyakarta: Universitas Islam Negeri Sunan Kalijaga, 2013)

Ika Susiloningsih, Supervisi Kepala Madrasah Dalam Meningkatkan Kompetensi Pedagogik Guru PAI Di Madrasah Aliyah Negeri Tambakberas Jombang, (Malang: Universitas Negeri M aulana M alik Ibrahim, 2016) 
Lexy J. Moleong, M etodologi Penelitian Kualitatif, (Bandung: PT. Remaja Rosdakarya, 2015),

Bahrun ali murtopo dan fatmawati 2016 . Upaya Madrasah Dalam Meningkatkan Prestasi Un Mi Imam Puro Lubangindangan Kec Butuh Kab Purworejo. Jurnal penelitian bidang pendidikan. Vol.22,No.2 : 109-119.

Nana Syaodih Sukmadinata, M etode Penelitian Pendidikan, (Bandung: PT. Remaja Rosdakarya, 2012),

Andi Prastowo, Memahami Metode-metode Penelitian, (Jogjakarta: Ar-ruzz Media, 2011),

Sugiyono, M emahami Penelitian Kualitatif, (Bandung: Alfabeta, 2010), hal. 92.

Hasil observasi di MI Ma'arif Adikarso Kebumen, pada 8 Oktober 2016.

Wawancara dengan Kepala MI Ma'arif Adikarso Kebumen Bapak Ahmad Suwardi, pada 10 Oktober 2016.

Wawancara dengan Ibu M urniati Guru Kelas V M I M a'arif Adikarso Kebumen, pada 12 Oktober 2016.

Wawancara dengan Ibu Puji Lestari Guru Kelas I MI M a'arif Adikarso, pada 11 Oktober 2016

Wawancara dengan Ibu Surati Guru Kelas I MI Ma'arif Adikarso, pada 29 September 2016. 